\title{
CORRUPTION IN NIGERIA: A CULTURE OR RETROGRESSIVE FACTOR?
}

\author{
Patrick Enoch Nmah* \\ http://dx.doi.org/10.4314/og.v13i 1.6
}

\begin{abstract}
This research work, corruption in Nigeria: a culture or retrogressive factor presented corruption as a curse and a complex social, political and economic phenomenon that affect all facets and the fabric of Nigerian society. Scholars and Nigerian government do not offer any realistic practical recipes in dealing with the pressing problems of corruption, economic hardship and underdevelopment in Nigeria in the $21^{\text {st }}$ century. Nigerians, especially leaders, politicians, civil servants, academia, some Christians and some religious leaders, found it difficult to practice the Christian values, which Jesus Christ himself exhibited perfectly during his earthly ministry. The proper examination of these problems engaged the aim of this paper. The method of approach is descriptive and phenomenological approaches based on the review of related literature.
\end{abstract}

Keywords: corruption, culture, bribe, extortion, policy, traditional gift, church, religion and social change.

\section{Introduction}

The history of Nigeria is characterized by corruption amplified by her encounter with the European imperialists. The encounter took three stages namely slave trade, the partition of Africa by the European powers who scrambled for territories therein, and the Christianization of Africa which occurred during the partition era (Uka, 1980, Ayandele, 1966). Corruption as a way of life in Nigeria is a kind of belief or practice that defies any reasonable solution, a deliberate attempt to set forth one line of argument so forcefully, as repeatedly, and so uncompromisingly that the learner is unable to consider other alternatives of better life styles. While traditional and religious values aim at producing people with dignity, identity with critical and analytical minds, corrupt officials' indoctrination tends to suppress the development of such minds. dependency theory tended to neglect factors internal to poor societies such as cultures or 
ethnic resistant to change, gender inequality, political corruption and the reckless misuse of available resources (Hornsby-Smith, 2006).

Corruption has been the foundations of the maladministration in Nigeria, the separation of each from the other and the cause of intra-and-inter-ethnic group conflicts. The aim of this paper is to create awareness of true and dignified style that is deeply rooted in traditional and religious values that will help the Nigerian citizenry to champion their governance ideas, and their activities intelligibly and spiritually. The methods of approach include descriptive and phenomenological methods.

\section{Conceptual framework}

Citing United Nations office on drug and crime (UNODC) in its "Action against corruption and Economic Crime", Onyiloha (2015) defined corruption as a, complete, social, political and economic phenomena that affect all countries. It undermines democratic institutions, and slows economic development. It attacks the foundation of democratic institutions by distorting electoral processes, perverting the rule of law and creating bureaucratic quagmires whose only reason for existing is the soliciting of bribes. Economic development is stunted, because foreign direct investment is discouraged and small businesses with the country often find it impossible to overcome the "start-up costs" required because of corruption.

The above description highlights major aspects of corruption and their negative impacts on the society. Given the importance of the fight against the scourge of corruption on a global scale, the United Nations (UN) has declared the " 9 th of every December as UN International Anti-Corruption Day." All member-states including Nigeria observe the day every year.

Corruption embraces a broad spectrum of activities ranging from fraud (theft through misrepresentation), embezzlement (misappropriation of corporate or public funds) to bribery (payments made in order to gain an advantage or avoid a disadvantages). Sen (1999) and Atlas (1968) described corruption from the sociological viewpoint as the violation of established rules for personal gains and profits. To Kunhiyop (2008), corruption is making someone morally corrupt or becoming morally corrupt by indulging in bribery, 
extortion, fraud, nepotism, outright theft, match-fixing, examination fraud, kickbacks, illegal awarding of contracts and the like. In the political spectrum, corruption occurs in rigging of election, the purchase and sale of votes and the falsification of elections' results. Furthermore, from a legal standpoint, Nigeria's Anti-corruption Law of 2010 (12), defines corruption as "gratification by an official": (1) any person who corruptly: a) asks for, receives or obtains any property or benefit of any kind for himself or for any other person. b) agrees attempts to receive or obtain any property or benefit of any kind or for himself or for any other person, on account of i) anything already done or omitted to be done, or for any favour or disfavour or disfavour already shown to any person by himself in the discharge of his official duties or in relation to any matter connected with the functions, affairs or business of-a government development, or corporate body or other organization or institution in which he is serving as an official; ii) anything to be afterwards done or omitted to be done or favour or disfavour to be afterwards shown to any person, by himself in the discharge of his official duties or in relation to any such matter as aforesaid, is guilty of an offence of official corruption..."

The global position on corruption has elicited responses from concerned organizations or agencies both in its study, analysis, and evaluation and one of such bodies is the Transparency International, a non-governmental organization (NGO). For such body, corruption is the abuse of entrusted power for private gain. Nigeria is presently suffering from systemic corruption which manifests itself in a near-decay of social infrastructure as well as a meteoric rise in a number of corrupt persons in the cross all fields of human endeavour.

The history of Nigeria is characterized by corruption amplified by her encounter with the European imperialists. The encounter took three stages namely slave trade, the partition of Africa by the European powers who scrambled for territories therein, and the Christianization of Africa which occurred during the partition era (Uka, 1980, Ayandele, 1966). To Igwe (2010), corruption occurs in any organized, interdependent system in which parts of the system are either not performing their dues as ethically 
expected or are performing them improperly to the detriment of the system's original scope.

Culture is a fundamental concept within the discipline of anthropology (Scupin, 2000) it offers meaning, purpose, and values to the socio-economic religious, political and aesthetic ethos of society (Obafemi, 2011). It is the main factor of determining one's identity, religion and relevance in community. According to Evwierhoma (2007), culture persuades everything a human being does, plans to do and not to do. It is mainly earned or acquired through instruction, interaction and other means of cultural transmission.

For Niebuhr (1956), culture is the "artificial, secondary environment" which man superimposes on the natural. It comprises language, habits, ideas, beliefs, customs, social organization, inherited artifacts, technical processes, and values. This "social heritage," this "reality italicize," which the New Testament writers frequently had in mind when they spoke of "the world," which is represented in many forms but to which Christians like other men are inevitably subject, is what we mean when we speak of culture.

To Taylor (1871), culture is that complex whole which includes knowledge, beliefs, arts, morals, laws, customs, and any other capabilities and habits acquired by man as a member of society. It is a way of life. The definition given to culture by Evwierhoma shall form my operational definition.

\section{Research objectives}

The objectives of the study include:

- To investigate the causes of corruption in Nigeria.

- To examine why the corruption seems to be institutionalize in Nigeria.

- To create the awareness to innocent citizens of Nigeria on some of the issues involved in the corruption.

- To investigate also the implications of corruption to African states including Nigeria.

- To proffer solutions on how to curb corruption in Nigeria. 


\section{Significance of the Study}

The significance of this basically stems from the fact that it addresses the issues that the unity, existence and development of Nigeria. The research work will try to offer a valid and insightful material those future religious, sociological, and anthropological scholars especially church historiographers can consult to gain useful information on the corruption in Nigerian society.

\section{Literature review and hypotheses Nigeria policy on corruption}

This research work examines the relevant policies on corruption as verified by the successive Nigerian governments from 1980s and up to the present period. The policies in review include such programmes or agencies as War Against Indiscipline (WAI), Economic and Financial Crimes Commission (EFCC), Independent Corrupt Practices and other Related Offences Commission (ICPC) and recent Buhari's Change begins with me as platforms to fight misconduct. These are juxtaposed to such anti-corruption bodies as the United Nations Organization (UNO), the United Nations Global Programme Against Corruption (UNGPAC), the United InterRegional Crime and Justice Institute (UICJI), the United Nations Code of Conduct for Law enforcement Officials (UNCCLEO), the Manual on Practical Measures Against Corruption (MPMAC), the Organization for Economic Cooperation and Development (OECI), the International Police Organization (INTERPOL), and Transparency International (IT).

An historical review of the military government of Buhari/Idiagbon shows some commendable efforts to tackle corruption and indiscipline, since perhaps, after the nation's independence. The administration launched what it called the "War Against Indiscipline (WAI)" as a platform to fight misconduct. Many Nigerians praised the good results of WAI. At this time, the country was almost relapsing into lawlessness, environmental degradation, economic bankruptcy, education without character, religion without sacrifice, moral decadence, among other cases of delinquency. The strategy deployed by the military to enforce the WAI policies was, however, considered to be too handy. Some people are of the views that persuasion is more effective than 
autocratic action with regard to the WAI campaign. Some argued that WAI would have been more successful of the military administration had brought in a coalition of professionals both at the stage of its design and also at the stage of its implementation.

Advance fee fraud (419) and other related corrupt practices flourished during and after Babangida's exist from office. Sani Abacha topples the "Government of National Unity"(GNU) hurriedly put in place by Babangida at the verge of his self-styled "stepping aside"linked to the alleged plan to perpetuate himself in office after he annulled the "June 12"presidential election. Ernest Shonekan headed the GNU. The Abacha military regime signed the "Anti-Fraud Code"(anti-419, using a Nigerian colloquial) into law. Thus the anti-fraud policy during and after Abacha's regime has suffered and continues to suffer owing to many current cases of fraudulent activities among some Nigerian government officials.

The Olusegun Obasanjo democratically elected government came in with some sort of a glimmer of hope in the overall fight against corruption by the signing into law acts establishing two foremost anti-corruption bodies namely, Economic and Financial Crimes Commission (EFCC) and the Independent Corrupt Practices and Other Related Offences Commission (ICPC). ICPC is the apex body vested by law with the responsibility to fight corruption and other related offences in Nigeria. It was set up and empowered by the Independent Corrupt Practices and Other related Offences Commission Act 2000, which was signed into law on June 13, 2000. The ICPC, therefore, was inaugurated on the $29^{\text {th }}$ of September, 2000 by President Olusegun Obasanjo, with a chairman and 12 members. Both ICPC and EFCC have the duties of fighting corruption in Nigeria since their enactments and there was a general acceptance by majority of Nigerians. However and with turnout of events, some Nigerians alleged that ICPC and EFCC suddenly had become government's tools for vendetta to political oppositions, non-loyalists and perceived enemies. This development derailed the hitherto merits credited to the anti-corruption bodies, and most unfortunately also, such perception has endured to the political dispensation under the administration of President Goodluck Ebele Jonathan. 
According to Kunhiyop (2008), corruption is a feature of African social, political and even religious life, with disastrous consequences. It not only impedes economic development, but also increase poverty by making a few individuals richer and many poorer. Corruption is making someone morally bankrupt, spiritually barren, and academic without character. corruption involves bribery, extortion, fraud, nepotism, kickbacks, outright theft, match-fixing, disobedient to court order, examination malpractice, illegal awarding of contracts and mal-administration. Bribery, for instance, is giving money or favour to someone who is in a position of trust, in order to pervert their judgment or corrupt their conduct. It is intended to make a person act illegally, unjustly or immorally. The responsibility for bribery rests with both the giver and the recipient.

Extortion comes from a word that means 'to squeeze; and refers to "the act of obtaining something, such as money from an entity (whether a person, group, corporate or institution) through threats, violence or the misuse of authority (Grenz and Smith, 2003). Fraud includes financial crimes such as forging cheques and inflating costs. It occurs also when "funds raised for such activities as famine, relief, bursary funds for poor children's school fees, and funds to assist the disabled within society are not put to the intended use. Nepotism occurs when someone appoints relatives and friends to positions of authority or awards them contracts. It often leads to the dominance of one ethnic group over another, which has negative implications for nation building (Kunhiyop, 2008). In the political sphere, it manifests itself in election rigging, the purchase and sale of votes and the falsification of election results.

The idea of appointing a retired military officer to head custom or immigration is a corruption in disguise. Likewise the defence ministry or police affairs or even ministries or parastatals. The government at any level should always appoint appropriate persons to appropriate offices to enhance service delivery. Federal government, state governments, local government councils, and political parties should stop re-cycling particular individuals for appointments as if the remaining citizens have nothing to offer towards the development of the councils, states and Nigeria at large. Parties submitting ex-convicts names to contest for elections is another way of institutionalizing corruption in the country. 


\section{Traditional gifts and bribes}

Those who hold public office are supposed to perform their duties without any external inducement. For example, when one is approaching the gods, one had to approach the gods with gift in hand to appease them for some wrong doing or to thank them for such things as a good harvest, the birth of a child or the coming of the first rains. Such a gift could never have been considered a bribe to induce a god to do something immoral, for the gods could do no wrong. When appearing before a chief, or king or the elders of the community, it was considered disrespectful and improper to appear before one's superiors empty-handed. The gift was not a bribe because the elders, who often acted as the judges, were expected to be just in their utterances and in the performances of their duties. When consulting diviners and priests who are regarded as intermediaries and who would carry out the will of the goods, bribing them to misconstrue what the gods were saying was unthinkable. Any attempt to do so would bring judgment (death for both the giver and the recipient). It is said that when someone did bribe a priest to help him obtain possession of some land, both the man and the priest who took the bribe died in a mysterious fire. When consulting medicine men and women, a gift was often necessary to ensure the effectiveness of the medicine prescribed. Given that some of these medicine men and women were prepared to use unorthodox and evil methods, the gift could well constitute a bribe to persuade them to use their powers to drive someone mad, kill someone or make someone fall in love. These examples show that the motive for giving something is important when determining whether it is or is not bribe.

\section{Consequences of Corruption}

The negative effects of corruption, according to Kunhiyop (2008), include:

- Erosion of moral values-It perverts a nation's sense of right and wrong. In a corrupt society, the right becomes the wrong and the wrong becomes right.

- Increased social evils-It provides fertile soil for tribalism, nepotism, fraud, dishonesty, selfishness, kidnapping, prostitution, human-trafficking, mal-administration, and 
armed robbery. It may also lead to murder, religious bigotry, civil war and other vices.

- Lack of transparency-Corruption encourages those in authority to shun transparency and accountability. Calls for public officials to be transparent and accountable elicit defensive and vindictive responses.

- Disregard for the rule of law-Corruption encourages individuals, entities and institutions to cut corners and ignore legal requirements. It leads also to unlawful detention of innocent citizens, perceived enemies and opposition party members by the Federal government. It can be extremely difficult to obtain justice under this situation.

Other consequences of corruption include oppression of the weak, loss of public trust, adoption of a utilitarian ethic, destruction of the moral fibre of society, poor productivity and incompetence, in effective development and administration, limited foreign and domestic investment, undermining of democracy, and general under development. Many Christians seem to accept or even benefit from corruption. The writers of scripture lived in a world where the situation with regard to bribery was similar to that which prevailed in traditional Africa, Nigeria inclusive. The word translated as "a bribe" in the Old Testament can denote "a reward" or "a gift" (Ex. 23:8; Dent. 16: 18-20; Is. 1:23). For the word extortion, which is demanding of a bribe, is also strongly condemned: "Extortion turns a wise man into a fool, and a bribe corrupts the heart (Eccl. 7:7). In Psalm 62:10, extortion is linked with robbery: "Do not trust in extortion or take pride in stolen goods; though your riches increase, do not set your heart on them"(cf. Is. 33:15; Jer. 22:17).

Other forms of corruption that are condemned include using dishonest scales to defraud purchasers (Hos. 12:7; Amos 8:5) and cheating one's neighbours of what is rightfully theirs (Lev. 6:2). The scriptures also condemn the type of abuse of the courts that led to Naboth's wrongful conviction and death and the king's seizure of his vineyard (1kgs. 21). Corruption is a vicious sin and crime against God and humanity. It is man's inhumanity to his fellow man. It destroys a nation and perverts its sense of right and wrong, good and bad. 


\section{Religion and social change in corrupt society}

During the periods of decolonization in Africa, there were changes in African countries. Most of these social changes attracted social changes between the individual and his community on one hand and between the relationship of man and the supernatural world.

In the post colonial period also the coming to power of new generation of African leaders restored the self-confidence of most Africans. This new leadership did not only give the average African the feeling of restored dignity and pride, but it also provided the motivation to accept modernization. This will to an extent change the material condition of African people. Since the colonial powers were not seriously interested in the development of the African personality and the material world of the average African as a result of corruption and racism, it fell on the shoulders of African leaders to do so. That is to show interest in the development of the African personality and society.

African in the first post-colonial period found it necessary to pursue modernization at all cost and as rapidly as possible. These African leaders and their people exposed themselves to a host of problems that usually accompany social change. In no area other than in the field of religion has the impact of social change been so evident. Modernization, according to most studies, brings into a society a multitude of problems. For example urbanization which is one of the processes of modernization ushers in a host of social adjustment problems which is one of the processes of modernization adjustment problems which may impact negatively on the religious situation of the society. Because of the moral and social disharmony that tends to accompany urbanization, religious groups usually emerge to address the issues of morality and social justice.

In the post colonial era three patterns or responses to social change can be identified.

1. The first pattern which has manifested itself all over the continent is the utilization of religious values to legitimate the role of the new African leaders, which should be emulated by the contemporary Nigerian politicians and leaders. 
2. The use of religious leaders with discernible mind to help rationalize theologically the modernization drive of the government which is necessary for good governance. This was more evident in Egypt under Nasser. During the 18 years of his rule he pursued his political and modernization drives by taking two important measures namely (a) the appointment of religious scholars known as the Ulema who were not only modernisers, but also sympathetic to his course.

(b) The second step he took was the requesting of fatwa-religious ruling from the moslem jurists which legitimize government programmes. In other words by requesting fatwa, Nasser was using sharia to justify government programmes.

The sad aspect of Nigeria's underdevelopment is that many youths have been contaminated with the consume-and-produce nothing virus by the elite. Nowadays the desire of most young ones in Africa particularly in Nigeria is to acquire the latest iphones and Sport Utility Vehicles without producing or investing in the economy or in their future. A great deal of Nigerian commonwealth has also vanished into private pockets since 1960 through official looting of the national treasury. These are funds that would have been used to provide quality, durable and subsidized education for generations of Nigerians yet unborn. The stolen funds could have been channelled into building world-class hospitals to treat the leaders and the led that often travel to overseas for medical treatment and check-up, secondary and tertiary institutions, power sectors, and other infrastructures that can propel development. Unfortunately, the poor masses and less privileged ones are the ones that will bear the brunt.

\section{The Church and corruption in Nigeria}

The Church as Christ body, the one Christ shed his blood for is a God's family, caring for and treating one another as parents, siblings and children. If that is the case corruption in the guise of religious mayhem, ecclesiastical commotion, nepotism, denominationalism, extremism, ethnicity, political bigotry, economic mismanagement, dictatorship, sin, poverty, injustice, marginalization, envy, covetousness, and hate speeches will give way. The consequent will be peace, love, unity, true spirituality, strong electoral and judicial 
institutions, quality leadership and total sacrifice on the side of the citizens. These challenges world be solved only when every Nigerian is sincere to patriotism and willing to make sacrifices for the growth of the country.

There must be filial piety between the rulers and their subjects. The rulers should not go about throwing public funds to select few people at the detriment of the masses and reasonable development. The gap between the rich and the poor in the society should be breached. The value of Nigerian currency should be sustained in a situation that one can use one naira to buy reasonable thing in the market. Unless these problems are addressed, Nigeria will still be far from the promise land. The rich frequently are wealthy precisely because they exploit and oppress the poor.

Proverbs 15:27 says that bribery promoted greed. To O' Donovan (1996), greed (the love of money) is a great evil and a sin before God. The New Testament teaches us, and human experience shows us, that greed destroys people (1Tim. 6:9). When people trust in money, they do not trust in God (1Tim. 6:17). People kidnap, steal, cheat, lie and kill because of greed. Many murders in the world happen every year because of the love of money. Countries go to war because of greed. Judas Iscariot betrayed Jesus Christ for the love of money (Matt. 26:14-15). As a result, Judas lost his soul. Bribery clearly promotes greed, and greed destroys both people and nations. Proverbs 17:23 and Deuteronomy 16:19 teach that bribery perverts justice.

Deuteronomy 16:19 adds that "a bribe blinds the eyes of the wise and twists the words of the righteous". Ecclesiastes 7:7 says, 'A bribe corrupts the heart'. Thus bribery contributes to the corruption of society. It makes life hard for everyone and causes economic recession for the country. How else on this earth can people be delivered from the evils of bribery if there are no courageous Christians in the society who will refuse to participate in this sinful practice? Many Christians have fallen into bribery because they believe that things cannot be accomplished in any other way. That can only be true if there is no God. As long as there is a God, the Christian can pray and ask the Lord to help him. If God can raise the dead, he can certainly answer such a prayer. A Christian who refuses 
to practice bribery, may have to endure suffering or persecution at the hands of evil men.

\section{Methodology}

This research work employed the use of descriptive and phenomenological approaches to the study. It used also primary and secondary sources to obtain data. The primary source involved oral interviews while secondary source included books, journals, and internet materials. These furnished me with the basic information that was necessary for the comprehension, insight and analysis of the relevant issue $\mathrm{x}$-rayed in this research work.

\section{Conclusion and recommendations}

This study evaluates the challenges of corruption in the Nigerian society. The need to enhance religious values in Nigeria is determined by the willingness on the part of the leaders and the led to be honest, prudent, equity and patriotic in their daily activities. It is discovered that corruption as a problem to Nigeria is characterized by economic sabotage, terrorism, kidnapping, armed robbery, human trafficking, prostitution, and the like which are responsible for ethnicity, religious extremism and under development in Nigeria. Corruption is both a culture and retrogressive factor in Nigeria.

To Onyiloha (2015), Nigeria is on the verge of a systemic collapse if indices of corruption continued unabated and such a reality, no doubt, has cast Nigeria into a bad light among the union of nations. Nigeria is dreaded among other nations because of its irredeemable carriage of corruption in almost all facets of life. The military, the political class and the general attitude have all been identified as some institutional frameworks fuelling a meteoric rise in the cases of corruption in Nigeria.

Having studied the present indices of corruption in Nigeria, the following recommendations are proffered to ameliorate the phenomenon so as to enthrone an ethical space in the national development compatible with global anti-corruption practices.

i. A total overhaul of the nation's psyche through ethical and moral orientation programmes. The orientation would provide a new template capable of tilting Nigerians' outlook to the things that 
matter in life, self-esteem, self-awareness, self-reliance, selfsupporting and self-renewal.

ii. A total restructuring of the present system of public governance in Nigeria to usher in a new ethical paradigm, explaining leadership as a role for those men and women who desire to serve the state and citizenry. When such leaders emerge, corruption shall diminish.

iii. The various anti-corruption and related bodies such as EFCC, ICPC, change begins with me, whistle blower policy or the police should be repositioned and revamped in structure and resources to be truly anti-corruption agencies that fight the malaise to the satisfaction of all and sundry. The current arrangement whereby EFCC is loaded with three functions investigating, prosecuting and recovering of looted assets, call for a review. The EFCC and ICPC should be merged and their functions merged too while a new name should be given it.

iv. Again, the federal character principles should be applied with less stringency, but with fairness among ethnic groups, state and local governments that are homogenous, to avoid creating cleavages and divisions where none may have, strictly speaking, existed. This will save such societies from undue polarization. The appointment of persons to various positions should be made from the best available in any group or section in the country. The present application of federal character principle is all bourgeoisoriented and does very little to relieve the plight of the masses of this country. For instance, the indigenization policy which put capital in the hands of a few Nigerians did not benefit the masses. The political system should arrest the exploitation of the masses and redress their feeling of insecurity. It is by tackling these crucial welfare issues that the great majority of Nigerians can develop a sense of national identity, patriotism, transcending parochial loyalties of ethnicity, religion, language and region. This can help in meeting the challenges of corruption, social justice and national integration through federal character principles in Nigeria.

v. There should be increase in accountability and transparency, good governance, tackling of corruption, addressing the causes of conflict, investing in people's education and health, improving 
access to clean water and sanitation, investing in infrastructure, agriculture and small-scale irrigation, improving Nigeria's capacity to trade, their access to the markets of the rich world, and facilitating their adjustment to new trade regimes.

Nigeria has a responsibility to curtail abuses and corruption, to improve upon the value of Nigerian currency, structures and a more equitable sharing of goods in the interest of the common good and future generations while avoiding undue nationalism, privatization that leads to job losses and inefficiency, and premature total liberalization of international trade.

Nigeria does not need atomic bomb, missiles, AK 47 guns, hand-cuffs or shackles and so on to invade good Nigerian citizens' houses in the name of 'order from above' instead of fighting corruption with equity, poverty, religious extremism, kidnappers, armed robbers, and the likes. What Nigerians desperately need are food, shelter, youth employment, peace, love, compassion, development, true democracy that is human oriented in nature, true federalism, inventions, quality leadership, and not dictatorship, autocracy, gun-butts vandals or security banditry/brigandage.

*Nmah, Patrick Enoch, Department of Religion and Human Relations, Nnamdi Azikiwe University, Awka-Nigeria, patricknmah@yahoo.com 


\section{References}

Atlas, S. H. (1968). The sociology of corruption: the nature, causes and prevention of corruption. Singapore: Hoong Fatt.

Ayandele, E. A. (1966). The missionary impact on modern Nigeria 1842-1914. London: Longmans, Green and Co.

Evwierhoma, M. (2007). Nigeria: a flourishing culture in diversity. Abuja: NICO.

Grenz, S. J. \& Smith, J. T. (2003). Pocket dictionary of ethics. Downers Grove: IVP.

Hornsby-Smith, M. P. (2006). An introduction to Catholic social thought. Cambridge: Cambridge University Press.

Igwe, S. C. (2010). How Africa underdeveloped Africa. Port Harcourt: Professional Printers and Publishers.

Kunhiyop, S. W. (2008). African Christian ethics. Nairobi: Hippo Books.

Niebuhr, H. R. (1956). Christ and culture. New York: Harper \& Row Publishers.

Nmah, P. E. (2002). The seven words on the cross: the good Friday message for sober reflection in the contemporary Nigerian society. Umuahia: Lintdsons Co-operative Publications.

Obafemi, O. (2011). Nigerian culture: an overview. In O. Obafemi $\&$ B. Ayakoroma (Eds.), Perspectives on cultural administration in Nigeria. Ibadan: Kraft Books.

O’Donovan, W. (1996). Biblical Christianity in African perspective. Carlisle: Paternoster Press.

Onyiloha, C. A. (2015). "An ethnical appraisal of Nigerian policy on corruption vis-à-vis global anti-corruption practices" in ANSU Journal of Arts and Humanities, Vol. 2, No 2; (July), 98-110.

Scupin, R. (2000). The anthropological perspective on religion. In R. Scupin (Ed.), Religion and culture: an anthropological focus, 115. New Jersey: Prentice-Hall.

Sen, A. (1999). Development as freedom. New York: Anchor Books. Uka, E. M. (1980). Movatorium, ideology or utopia? A sociological interpretation of an African response to Christian mission. Unpublished PhD Dissertation. Drew University, Madison, New Jersey. 